\title{
Entrepreneurship Education: Orang Asli and Learning Experience
}

\author{
Siti Asma’ Mohd Rosdi ${ }^{\mathrm{a}}$, Ahmad Amri Zainal Adnan ${ }^{\mathrm{b}}$, Norsamsinar Samsudin ${ }^{\mathrm{c}}$ \\ a, b,c Faculty of Management and Economics, Universiti Pendidikan Sultan Idris, Perak, Malaysia \\ Corresponding author: a.amri@fpe.upsi.edu.my
}

To cite this article (APA): Zainal Adnan, A. A., Mohd Rosdi, S. A., \& Samsudin, N. (2020). Entrepreneurship education: Orang Asli and learning experience. International Business Education Journal, 13(1), 50-59. https://doi.org/10.37134/ibej.vol13.1.4.2020

To link to this article: https://doi.org/10.37134/ibej.vol13.1.4.2020

\begin{abstract}
Understanding entrepreneurship concept is indispensable in formal education system to support entrepreneurship education especially in school and higher education institutions. However, the need to understand entrepreneurship concept is essential and important as every individual has the potential to be an entrepreneurs. This study aims to assess the understanding of entrepreneurship concept among Orang Asli after playing a game; and to remark the emotional connotation after playing the game. This paper employed qualitative method in the form of observation and interview with 20 Orang Asli Semai in Perak state. The findings indicated that most participants showed basic understanding of entrepreneurship and developed positive connotation while playing the game. The study drew attention to the importance of learning through playing in non-formal learning especially among the Orang Asli community.
\end{abstract}

\section{Keywords}

Learning through playing, entrepreneurship education, Orang Asli

\section{INTRODUCTION}

Learning is a process of interaction between students, educators and learning context. How people learn and what people learn are important in achieving a successful learning. In order to improve education, course instructors need to provide more practical and use responsive teaching strategies (Kristen \& Schellhase, 2008). The development of science and technology affects the teaching strategies in education system as in the industrial revolution (IR) 4.0 nowadays, emphasize the creative and innovative teaching technique. Education is one of the important aspects of life to produce knowledgeable people. To achieve that goal, it requires an effective learning process. Thus, education and learning are interconnected. Previous literature proved that effective learning techniques can increase student motivation (Ninda, Khairul, \& Leny, 2017; Agung Setya, 2017).

There are various learning techniques including the utilization of learning media and the adoption of technology in learning such as visual media, audio media, audio-visual media, software multimedia, and game-based learning. Game-based learning or namely gamification is an innovative approach in education used in a flexible context, either formally in a classroom, or informally outside a classroom (Wee Hoe, 2016). It is relatively new in Malaysia (Wee Hoe, 2016). According to Wee Hoe, (2016) the technique is a student-centred learning, which helps students to learn and develop their skill by creating or playing game to deliver complex educational content. Learning components are delivered through the 
gamification process that relates the level of knowledge, thinking skills, capability, and emotion.

This paper offers perspectives of a non-formal entrepreneurship education for Orang Asli community specifically the learning through playing approach. According to Hassan et al. (2016), teaching methods and training are the enablers of education through action (learning by doing), involvement in real situations, case studies, and the sharing of knowledge by entrepreneurs. Thus, this study aims to contribute to body of research about learning within a non-formal education context, which offers insight into the practices of learning through playing, for the Orang Asli community in Malaysia. Learning through playing was selected because this approach provides a fun learning environment to motivate learners during the learning process. In detail, this study attempted to describe the Orang Asli's understanding of entrepreneurship after playing a specifically design entrepreneurship game.

In the following section, past studies on learning through playing in non-formal education are thoroughly discussed. Subsequently, elaborated description was provided in terms of the research methodology, underpinning theory, and the description of the project. Next, we present and explain the findings and discussion corresponding to the research questions. Finally, we end the article with a conclusion and demonstrate how learning through playing contributes to entrepreneurship education in non-formal learning context with respect to the selected sample of Orang Asli in this study.

\section{LITERATURE REVIEW}

\section{Learning through playing (LTP) in non-formal education}

Education and learning is overlapped, but they can be differentiated according to specific characteristics (Norqvist \& Eva Leffler, 2017). Previous studies stated that there is no single definition of learning and education. As stated by Bateson (1972), learning denotes a process of receiving information from an external source, which can be adapted later to a similar event to carry the same information and conclude that learning is a process that initiated through a stimulus that makes change happen. Formal learning is associated with an institution and takes place within the formal education system. Non-formal learning is connected to an institution (i.e. an organisation or association with a specific interest such as culture or sports) within the non-formal education system (Norqvist \& Eva Leffler, 2017). Non-formal learning occurs in a planned but highly adaptable manner in institutions, organizations, and situations beyond the spheres of formal or informal education. It shares the characteristic of mediated formal education, but the motivation for learning may be intrinsic to the learners (Eshach, 2007). From an international perspective, the values and needs of non-formal learning were understood differently according to various goals for the development of learning and education, which is considered as benefitting individuals and/or organisations (Ahmed, 2014). Furthermore, informal learning is mentioned in relation to formal and non-formal approaches; however, it differs in that informal learning does not subscribe to the systemic organisation, which should characterise formal or non-formal learning. Thus, it should be noted that informal learning is not a focus of this article. Table 1 provides some distinction between formal, non-formal and informal education. 
Table 1: The differences between formal, non-formal and informal education

\begin{tabular}{lll}
\hline \multicolumn{1}{c}{ Formal } & \multicolumn{1}{c}{ Non-formal } & \multicolumn{1}{c}{ Informal } \\
\hline Usually at school & At institution out of school & Everywhere \\
\hline May be repressive & Usually supportive & Supportive \\
\hline Structured & Structured & Unstructured \\
\hline Usually prearranged & Usually prearranged & Spontaneous \\
\hline $\begin{array}{l}\text { Motivation is typically more } \\
\text { extrinsic }\end{array}$ & $\begin{array}{l}\text { Motivation may be extrinsic but it } \\
\text { is typically more intrinsic }\end{array}$ & Motivation is mainly intrinsic \\
\hline Compulsory & Usually voluntary & Voluntary \\
\hline Teacher-led & May be guide or teacher-led & Usually learner-led \\
\hline Learning is evaluated & Learning is usually not evaluate & Learning is not evaluated \\
\hline Sequential & Typically non-sequential & Non-sequential \\
\hline Source: & & \\
\hline
\end{tabular}

Source: Eshach, (2007)

In this study, learning is the process of understanding entrepreneurship that involves cognitive domain and knowledge. Houwer, Barnes-Holmes, and Moors, (2013) studied detailed functional definition of learning, not only does it solves problems related to other definitions of learning, but also it is compatible with and has advantages for cognitive learning in psychology. The cognitive approach in learning psychology aims to explain learning effects in terms of mental constructs.

Studies on learning through playing are often associated with children's learning (Kennedy \& Lennie Barblett, 2009). Play has been central to the practice of experiential learning; be it games, role-plays, outdoor adventure training or "playing" with ideas in the creative process. There has been to our knowledge, however, no systematic examination and application of the extensive literature on play to these activities (Kolb, 1984). Is it possible to create a learning environment that integrates play and learning? Kolb and Kolb (2010) proposed a holistic model that viewed play and learning as a unified and integral process of human learning and development. They introduced the concept of ludic learning space, wherein learners achieve deep learning through the integration of intellectual, physical, moral, and, spiritual values (Kolb, 1984) in a free and safe space that provides the opportunity for individuals to play with their potentials and ultimately commit themselves to learn, develop, and grow. There are studied showing that learning through playing or gamebased learning is possible (Kolb \& Kolb, 2010; Olga, Malliarakis, Tomos \& Mozelius, 2017). Several research studies were carried out and corresponding games were developed that aim to include the aforementioned features to support learning and teaching.

Dart game is one of the most popular games, because it contains elements of probability expected to be interesting and fun so it can create a conducive learning environment. Entrepreneurship Dart Game is the application of modified dart game. In this game, the students (players) are assigned to throw arrows (darts) to the dartboard that has been prepared. The dartboard has numbered columns of 1-20 and four colour-coded areas; one secret box in black and three categories of questions: green colour indicates the easy category; red indicates medium and yellow is difficult. The dartboard also has a red midpoint indicating 20 points of bonus without solving the problem. In this game, players will work in groups to solve questions and then submit the agreed answers to the teachers (game master), so it is expected to create good interactions between students and students with teachers. Previous studies have been examining the use of dart game in teaching and learning, for example Agung Setya, (2017) and Ninda, Khairul, and Leny (2017). 


\section{METHODOLOGY}

\section{Participants}

There were 20 Orang Asli Semai in Perak selected in this study. The structured random sampling was applied and the common selection criterion of these participants was that they do not have registered business and need more knowledge and basic support to start-up a small business. Therefore, they need to understand the basic concept of entrepreneurship. All of them were selected from an Orang Asli village and they belonged to the same tribe, which is Semai. They were generally in a similar stage, where they were in the process to understand and trying to start-up their businesses. Most participants' were approximately 25 to 45 years old, and most of them finished primary school, except for five interviewees who finished the secondary school and obtained Sijil Pelajaran Malaysia (SPM).

\section{Data Collection Procedure}

To obtain an in-depth and rich understanding, the researchers used observation and interview in this qualitative study. When the participants were playing the game, the researcher performed an observation to acknowledge the extent of respondents' understanding about the basic entrepreneurship concepts. The observation and interview were conducted in February 2018 at a Chinggung Village Multipurpose Hall. Malay language was used as the primary language in the interviews with the participants and the interviews were held after the game was played. All interviews were recorded, transcribed verbatim and translated into English by a professional transcriptionist. Consent to participate in the research was also obtained from the participants to record the interview. The interviews lasted for half an hour on average. In order to assess the understanding/remark of the participants when they learned through playing the dart game, the following objectives were used as the general guideline: [1] the participants' understanding of entrepreneurship concept after playing the game; [2] the remark (connotation/feeling/comment) after playing the game. Thus, the interview questions were structured as follows:

(1) What is the entrepreneurship?

(2) What is the remark/feeling or comment (s) about the game?

The existing literature significantly indicated the inadequate, readily available information on assessing the understanding on entrepreneurship concept through playing among Orang Asli. As Benbasat, Goldstein and Mead (1987), case study allows the study of a phenomenon of interest in its natural setting. In this case, this research chose the Orang Asli based on the spill over effects to the rural community in terms of employment and business opportunities. The Orang Asli who live in rural area were chosen as the research participants based on the argument proposed by McElwee and Smith (2014) that rural community is a group of people that have enormous potentials to be developed into entrepreneurs. Ozden (2008) argued that some of the effective methods for teaching minority groups such as the aboriginal people should be implemented. However, there has been limited literature and empirical data to support this contention. In response, this study assesses the understanding of the participants about the entrepreneurship concept through playing the dart game. 


\section{The justification of the dart game use}

In this study, learning though playing was practiced through the dart game. The implementation of the game was modified based on a learning game carried out in a pilot study conducted earlier on a village chief known as Tok Batin, as well as 10 Orang Asli of Chinggung. The results of the pilot study showed that the dart games were suitable for learning purposes, and enhanced the interest of the Orang Asli to learn. Therefore, this study applies dart games as one of the learning through playing techniques because the dart game method requires the player to play the game by aiming at precise points on the dartboard. Orang Asli have the critical skills developed from their daily routines to win this game.

\section{The implementation of the dart game}

Game-based learning was applied to the Orang Asli by first identifying the competing groups before the learning begins. The game was specially designed to accommodate the competence of the Orang Asli. For example, the use of language, the level of difficulty, the type of skills, the level of thinking and the appropriate tone were taken into account in creating this game. The researchers used five original game building elements as suggested by Prensky (2007), for example; (1) Rules, (2) Goals, (3) Challenges, (4) Interactions and (5) Feedback. However, the researchers did not include the Narrative element to reduce the difficulty of the game to facilitate the implementation and understanding of the participants. The game genre is a combination of board games and puzzle games.

\section{Rules}

Before starting the game, the researchers described the rules of the game to the participants. The rules of the game are as follows:

a. Distance: The distance from the dartboard and the player was 7 feet.

b. Group Distribution: The players were divided into two groups where each group has 5 pairs of players. The two groups were named A and B. Each player from group A and B will take turn to throw the darts to the dartboard.

c. Score Determination: A score will be given to participants who can answer simple questions about entrepreneurship. If the participants answer the question correctly, 5 marks will be awarded and the score will be grouped according to each group. The group that collects the most marks will be considered as the winner.

\section{Goal}

The player does not have to focus on scores, but just need to keep the darts on any part of the dartboard. The goal in this game is to experience fun learning and provide knowledge about entrepreneurship to the players.

\section{Challenges}

The next step is setting the Challenge. The challenges in this game involve answering the questions. The existing numbers on the dartboard was used to set questions about entrepreneurship basic concepts. When players threw the darts on any number on the dartboard, the player is obliged to answer the predetermined question based on the number. Each correct answer was scored. The player's challenge is to correctly answer each question to get the highest score. 
There were 10 questions that were prepared corresponding to the numbers on the dartboard. Since the dartboard has 20 numbers, the researcher only selects 10 numbers to assign questions related to the entrepreneurship concepts. The questions are stated in Table 1.

Table 1: Selected numbers and questions

\begin{tabular}{cl}
\hline Number & \multicolumn{1}{c}{ Questions } \\
\hline 2 & In your opinion, what do you think about entrepreneur? Answer in your own word. \\
\hline 5 & Entrepreneurs are people who dare to take the risk. Right or wrong? \\
\hline 6 & You like to catch a fish. What do you do if there is a surplus of catches? \\
\hline 7 & $\begin{array}{l}\text { Business ideas obtained if you are thinking of solving business-related problems. } \\
\text { Right or wrong? }\end{array}$ \\
\hline 12 & $\begin{array}{l}\text { You love to search for forest produce, and what will you do if you have lots of } \\
\text { forest produces? }\end{array}$ \\
\hline 15 & $\begin{array}{l}\text { In your opinion, what do you think about entrepreneurship? Answer in your own } \\
\text { word. }\end{array}$ \\
\hline 17 & $\begin{array}{l}\text { Be friends with people and entrepreneurs can give opportunity in business networks. } \\
\text { Right or wrong? }\end{array}$ \\
\hline 19 & $\begin{array}{l}\text { In your opinion, do you have the intention to start a business? } \\
\text { business? }\end{array}$ \\
\hline 20 & $\begin{array}{l}\text { Provide examples of the products / services you may offer if you become an } \\
\text { entrepreneur. }\end{array}$ \\
\hline
\end{tabular}

4. Interaction

For the Interaction element, the social interaction mode (Adams, 2010) was adopted where players should focus on: [1] interacting competitively with the competing groups, and [2] cooperate in their own set of game.

\section{Feedback}

Feedback in this game refers to the response given when players answer the questions and also responses when playing dart. The feedback is formatted throughout the game, and after the game ends.

\section{FINDINGS}

\section{Profile of Participants}

Table 2 below describes the respondent's profile. All participants were Orang Asli from Semai tribes that comprised of $65 \%(\mathrm{~N}=13)$ females and $35 \%(\mathrm{~N}=35)$ males. Pertaining to the education level, majority of them completed primary school only which accounted for $75 \%$ $(\mathrm{N}=15)$, while 15\% ( $\mathrm{N}=5)$ obtained Sijil Pelajaran Malaysia (SPM). None of them pursued their studies to the tertiary level of education. $85 \%(\mathrm{~N}=17)$ of the participants were married, whereas $15 \%(\mathrm{~N}=3)$ were single. On regards to the types of occupation, the samples were dominated by housewives that corresponded to $50 \%(\mathrm{~N}=10)$ of the overall sample, $35 \%$ $(\mathrm{N}=7)$ of them was working in private cleaning services and only $15 \%(\mathrm{~N}=3)$ of them was self-employed. 
Table 2: Participants' demographic profile

\begin{tabular}{llcc}
\hline Demographic & & Frequency (N) & Percentage (\%) \\
& & & \\
\hline Gender & Female & 13 & 65 \\
& Male & 7 & 35 \\
\hline Education level & Diploma/Degree & 0 & 0 \\
& SPM & 5 & 25 \\
& PMR & 0 & 0 \\
& UPSR & 15 & 75 \\
\hline Marital Status & Married & 17 & 85 \\
& Single & 3 & 15 \\
\hline Occupation & Housewife & 10 & 50 \\
& Private sector & 7 & 35 \\
& Public sector & 0 & 0 \\
& Self-employed & 3 & 15 \\
\hline
\end{tabular}

\section{Findings of the observation}

The observation was carried out when respondents were playing the dart game. As mentioned earlier, the observation was used to observe the behaviour of the participants throughout the game. While observing throughout the process, the researchers found that the participants were very active, excited and entertained by this game. They laughed when answered correctly to the questions given.

After the game ended, the participants were allowed for recess for 10 minutes. Then, the researchers asked several questions, including "How was this game, is it fun?" The participants raised their hands in agreement.

\section{Findings of the interview}

The analysis of the interviews was presented in Table 3. Two themes were created to conclude [1] the understanding of the entrepreneurship concept; [2] the remarks/feeling/comment of participants when they played the game.

\section{Table 3: Findings of the interview}

\begin{tabular}{|c|c|}
\hline Themes & Excerpts \\
\hline $\begin{array}{l}\text { Theme 1: The understanding of the } \\
\text { entrepreneurship concepts (based on the } \\
\text { participants' answers to questions asked } \\
\text { during the game) }\end{array}$ & $\begin{array}{l}\text { When asked "What is entrepreneurship?", some of the } \\
\text { response were recorded as below: } \\
\text { - "Entrepreneurship is business activities" (F4; } \\
\text { - F5;F6;F8;F11) } \\
\text { "Entrepreneurship is selling product" (F11; } \\
\text { F7; F8; F9; M1;M3) } \\
\text { "Entrepreneurship is gaining profit in } \\
\text { business" (F9; F10;F11;M1;M2;M3) }\end{array}$ \\
\hline $\begin{array}{l}\text { Theme } 2 \text { : The } \\
\text { remark/connotation/feeling/comment } \\
\text { (after the participants played the game) }\end{array}$ & $\begin{array}{l}\text { The participants sincerely expressed their opinions on } \\
\text { their feeling/remark and commented about the game. } \\
\text { Some of their responds were recorded as below: } \\
\text { - "I feel good and interested in playing this } \\
\text { game" (F3;F4;F7;F9; F10;F18;) } \\
\text { "This game can be used for learning purposes } \\
\text { because students will answer questions to } \\
\text { score" (M1;M2;F1;F3) }\end{array}$ \\
\hline
\end{tabular}




\begin{tabular}{ll}
\hline Themes & Excerpts \\
\hline$\bullet$ & "Want to play this game again $(F 7 ; F 8 ; F 9 ;$ \\
& F10;F11;M1;M2;M3) \\
& "Fun and interesting" $(M 1 ; M 3 ; F 4 ; F 17 ; F 20)$
\end{tabular}

\section{DISCUSSION}

Entrepreneurship education is an emerging issue in Malaysia. This is in relation to the important role played by rural entrepreneurship in supporting the economic development of the nation. A dynamic economic development and several uncertainties had created numerous business opportunities for future entrepreneurs, including rural communities. Hence, to educate entrepreneurship education in non-formal learning, the creativity and innovative approach needed. From the observation and interview, it can be concluded that the majority of the participants were benefited from the game. In fact, a few of them suggested that this game should be applied in classroom and used for learning purposes because students will answer the questions to gain scores. This is also in line with Wee Hoe, (2016) who suggested that game-based learning as a flexible approach as students can learn formally in classrooms or informally outside the classrooms to motivate them to learn.

In relation to the finding, this game focuses on the potential of a participant regardless of his age and capability as the learning outcome of the game is focused on the cognitive element (when answering the question). The game empowers the participants to understand and answer questions about entrepreneurship basic concepts; teamwork skills; and entrepreneurship thinking skills. With regard to the first theme, the participants understood that entrepreneurship is a business activity. The participants could relate the basic concept of entrepreneurship while undergone meaningful learning process through playing the dart games. This finding is supported by Adams (2010) who argued that the best way to learn is through direct purposeful experience and more real-life experiences could be embedded by instructors in designing effective instructional activities. Kolb (1984) supported that experience was essential as the source of learning and development of knowledge. Gamesbased learning is usually most effective when all sensory was used optimally. Participants will be able to learn to do their work on their own (learning by doing). The second theme emphasized on the participants' feeling or connotation about the game and they concluded that the game was fun and interesting to be played again. Usually, game-based approach involved the elements of competition and reward (present) that can create participants' excitement and motivation to be the winner.

\section{CONCLUSION}

Learning is a continuous process and an entertaining learning environment can enhance motivation for students or in this study, the research participants during the learning process. Learners now have many opportunities to connect to spaces of information, communication, learning and education with the help of information and communication technologies (ICTs) which are increasingly available in education and society as a whole (Norberg et al. 2011; Floridi 2014; Jahnke 2016), and which can also be described as ubiquitous learning (Cope \& 
Kalantzis 2009). According to several studies, entrepreneurship education can foster an entrepreneurial culture. The development from industrial-based employment to selfemployment has accelerated over the years (Norasmah \& Norfadhilah, 2016). In this context, rural community must tap into the opportunities and infrastructure provided by the governments to produce quality human capital and manpower that possess the attributes and values that are the hall marks of entrepreneurship. Future studies are proposed to take into consideration the place, design, duration and capabilities of the participants based on the learning needs. If the game-based learning aims to measure higher order thinking skills, the game-based learning design should be able to measure that skill. In relation to non-formal learning context, learning is not necessarily performed in formal environment. For example, game-based learning involving exploration and challenges such as the exploration race that highlighted on the personality of entrepreneurs. With the innovative teaching and learning increasing more attention in education system, the findings of this paper strongly support the government's move to introduce an entrepreneurship education for society. An earlier exposure on entrepreneurship might be useful to reduce the number of business failure among Orang Asli particularly in rural entrepreneurship context.

\section{REFERENCES}

Adams, E. (2010). Fundamentals of Game Design. California: New Riders.

Agung, Setya., S.P. (2017). Pengembangan Media Pembelajaran Dart Game Accounting Untuk Meningkatkan Motivasi Belajar Kompetensi Mengelola Kas Kecil Kelas X Keuangan SMK Muhammadiyah 1 Prambanan Klaten Tahun ajaran 2016/2017. Program Studi Pendidikan Akuntansi Jurusan Pendidikan Akuntansi Fakultas Ekonomi Universitas Negeri Yogyakarta.

Ahmed, M. (2014). Lifelong learning in a learning society: Are community-learning centres the vehicle? In G. Carbonnier, M. Carton, \& K. King (Eds.), Education, learning, training critical issues for development (pp. 102-125). Leiden, NL: Martinus Nijhoff Publishers.

Bateson, G. (1972). Steps to an ecology of mind: collected essays in anthropology, psychiatry, evolution, and epistemology. San Francisco: Chandler Publishing Co.

Eshach, H. (2007). Bridging in school and out-of-school learning: formal, non-formal, and informal education. Journal of Science Education and Technology, (16), 2, 171-190.

Hassan, H., Norasmah, O., Hanim, K., Wan Mimi, W.Z. \& Sarmila, M.S. (2016), "Entrepreneurship education in UKM: essential skills for first year students", Proceeding International Conference on Leadership, Innovation and Entrepreneurship as Driving Forces of the Global Economy (ICLIE). Organized by Canadian University, Dubai, (April 20-22, di Atlantis - The Palm, Dubai).

Houwer, J. D., Barnes-Holmes, D., \& Moors, A. (2013). What is learning? On the nature and merits of a functional definition of learning. Psych on Bull Rev, 20:631-642.

Kolb, A. Y., \& Kolb, D, A. (2010). Learning to play, playing to learn: A case study of a ludic learning space, Journal of Organizational Change Management, 23 (1), 26-50. 
Kolb, D. A. (1984). Experiential learning: Experience as the source of learning and development. Upper Saddle River, NJ: Prentice Hall

Kristen, C. Schellhase. (2008). Applying mastery learning to athletic training education, Athletic Training Education Journal, (3) 4, 130-134.

Kennedy, A., \& Barblett, L. (2009). The Early Years Learning Framework: Learning and teaching through play. Australia: Elect Printing, Canberra.

McElwee, G., \& Smith, R. (2014). Rural entrepreneurship. In A. Fayolle (Ed.), Handbook of research in entrepreneurship. Cheltenham, UK: Edward Elgar.

Ninda, A., Putri, C., Khairul, B., Leny, L. (2017). Efektivitas Teknik Permainan Simulasi dengan Menggunakan Media Dart Board untuk Meningkatkan Motivasi Belajar Siswa Kelas VII C SMP Negeri 2 Tegal Siwalan Probolinggo. Jurnal Konseling Indonesia, (3) $1,22-27$.

Norasmah, O., \& Norfadhilah, N. (2016). Entrepreneurship education programs in Malaysian polytechnics, Journal of Education and Training, (58) 7/8, 882-898.

Norqvist, L., \& Leffler, E. (2017). Learning in non-formal education: Is it "youthful" for youth in action?. Int Rev Educ., 63:235-256.

Ozden, M. (2008). Improving science and technology education achievement using masterylearning model. World Applied Sciences Journal, (5)1, 62-67.

Olga, S; Malliarak, C.; Tomos, F., Mozelius. (2017). European Conference on Games Based Learning; Reading: 571-576. Reading: Academic Conferences International Limited.

Prensky, M. (2007). Digital Game-based Learning. New York: Paragon House.

Wee Hoe, Tan. (2016). Gamifikasi dalam Pendidikan. Pembelajaran berasaskan Permainan. Perak: Penerbit Universiti Pendidikan Sultan Idris. 